\title{
ARTIGOS
}

\section{CARTOGRAFIAS DO DESIGN: MEMÓRIA E COTIDIANIDADE DO MARAJÓ DAS FLORESTAS EM MOBILIÁRIO DE JUPATI}

DESIGN CARTOGRAPHIES:MEMORY ANDQUOTIDIANOFFORESTMARAJOINA JUPATIFURNITURE

\author{
NINON ROSE JARDIM, M.SC. |UEPA \\ MANOELA MARIA COSTA DA COSTA | UEPA \\ MARIANA FARO, M.SC. | NAEA
}

\begin{abstract}
RESUMO
O presente artigo aborda uma experiência de co-criação realizada pelo coletivo de designers Design em Rede. $\mathrm{O}$ objetivo do projeto foi criar uma linha de mobiliário que representasse as memórias e a relação do cotidiano dos artesãos ribeirinhos da comunidade Cristo Rei (São Sebastião da Boa Vista, Ilha do Marajó, PA).

À luz da metodologia do co-design, os produtos são resultado do entrelaçamento de saberes técnicos e tradicionais de designers e artesãos. A linha foi projetada a partir de atravessamentos sobre o uso da tala de Jupatí, palmeira nativa da flora amazônica, tradicionalmente utilizada pela comunidade para produção do matapi, armadilha para pesca de camarão nos rios da região.
\end{abstract}

PALAVRAS CHAVE: Design; artesanato; comunidade; co-criação; Amazônia

\begin{abstract}
This article approach a cocreation experience performed by the design collective called Design em Rede. The Project aim was to develop a furniture line which depict the memorie and quotidian relationship of artisians and riverines of Cristo Rei community (São Sebastião da Boa Vista, Marajo Island, PA).

Developed trohough a co-design methodology the products result of a mix of traditional and techinician knowledge of artisians and designers. The line was designed from crossings on the use of the Jupati splint, a native palm of the Amazon flora, traditionally used by the community to produce matapi, a shrimp fishing trap common used in the region's rivers.
\end{abstract}

KEY WORDS: Design; handcraft; comunity; co-criation; Amazon 


\section{INTRODUÇÃO}

O projeto foi desenvolvido objetivando criar uma linha de mobiliário que identificasse aspectos relevantes do cotidiano e modos de ser e viver da comunidade de artesãos ribeirinhos da comunidade Cristo Rei (São Sebastião da Boa Vista, llha do Marajó, PA). Através de metodologia própria, embasada na alteridade do território e na cartografia sensível, foram registrados o processo produtivo, o cotidiano e as formas diferentes de olhar a matéria prima local, que aliadas às percepções dos designers, contemplaram na linha de mobiliários em Jupatí.

O resultado foi uma linha de produtos que buscou diversificar e potencializar a produção dos artesãos locais, gerando renda para os produtores através de artefatos que carreguem a memória e a relação de cotidianidade ribeirinha marajoara.

\section{ENTRELAÇANDO SABERES}

Ao planejar um projeto de valorização de produtos locais é necessário compreender o espaço onde nascem tais produto, sua história e suas qualidades, associadas ao território e à comunidade de origem (KRUCKEN, 2009). Para isso, sensibilidade e envolvimento por parte do designer são fundamentais para que ele possa se aprofundar nas características do trabalho do grupo e consiga identificar pontos a serem conservados e pontos que devem ser aprimorados coletivamente. Neste sentido, este projeto tem por solo epistemológico os trabalhos de Ninon Jardim (2013; 2012), Lia Krucken (2009), Eduardo Barroso Neto (1999) e Adélia Borges (2003; 2011), para tratar da relação design, artesanato e território; Maristela Ono (2005), Rafael Cardoso (2012) e Nestor Garcia Canclini (1998) no que se refere às questões da relação entre design e cultura; Dijon de Moraes (2010), Lia Krucken (2009) e Lucy Niemeyer (2009), nas discussões quanto à metodologia projetual no design .

Estes movimentos de reflexão crítica e produção de um pensamento novo sobre a atividade projetual e suas interfaces com a cultura, foram a base para o desenvolvimento de uma metodologia própria, experimentada de forma prática pelo coletivo.

\section{CAMINHOS ENTRETECIDOS}

Como se demonstrou essencial na construção da metodologia relatada neste trabalho, não foram percorridos caminhos unidimensionais do ponto de vista do conhecimento. Partimos, sim, de uma perspectiva interdisciplinar, com reconhecimento central da relevância de um processo de imersão nos cenários onde a pesquisa se desdobrara. Tal processo se faz necessário para
O conhecimento da matéria prima, a prática das técnicas e as referências culturais desenvolvidas pelos grupos, bem como o conhecimento, a identificação e análise do lugar, das pessoas em suas relações sociais, culturais, estéticas e históricas. (JARDIM et al., 2015, p. 4)

Nesse sentido, a História Oral e a Cartografia puderam fornecer preciosas contribuições ao entendimento dos usos da oralidade e à "identificação dos sujeitos sociais, seus modos, expressões, atitudes" (JARDIM, 2013, p. 26) no processo de design, especialmente ao incorporarmos a prática cartográfica como percurso metodológico para inscrição de processos e narrativas de subjetivação. Também são incorporadas contribuições ao fazer cartográfico nos cenários de atuação, a partir do entendimento trazido por Krucken (2009) das oitos ações para potencializar produtos locais:

RECONHECER as qualidades do produto e do território.

ATIVAR as competências situadas no território.

COMUNICAR o produto e o território.

PROTEGER a identidade local e o patrimônio material e imaterial.

APOIAR a produção local.

PROMOVER sistemas de produção e de consumo sustentáveis.

DESENVOLVER novos produtos e serviços que respeitem a vocação e valorizem o território.

CONSOLIDAR redes no território (KRUCKEN, 2009, p. 68)

$\mathrm{O}$ reconhecimento das qualidades do produto e do território são base para trazer à tona as percepções do lugar, explorando os sentidos do habitat, as cenas do cotidiano, a paisagem geocultural, enfim, a vida.

O sentido de cartografia que será usado no texto está de acordo com as reflexões de Martin-Barbero (2004), que dilui o entendimento da cartografia moderna como apenas representação de fronteiras, apresentando-a como construção também de imagens das relações e dos entretecimentos dos caminhos. Em Martin-Barbero (2004, p. 12) apreende-se "[...] uma lógica cartográfica fractal [...] que se expressa textualmente, ou melhor, textilmente: em pregas e des-pregas, reveses, intertextos, intervalos". Uma lógica arquipélago, "[...] lugar de diálogos e confrontação entre as múltiplas terras-ilhas que se entrelaçam" (MARTíN-BARBERO, 2004, p. 13 apud JARDIM, 2013, p. 23). 


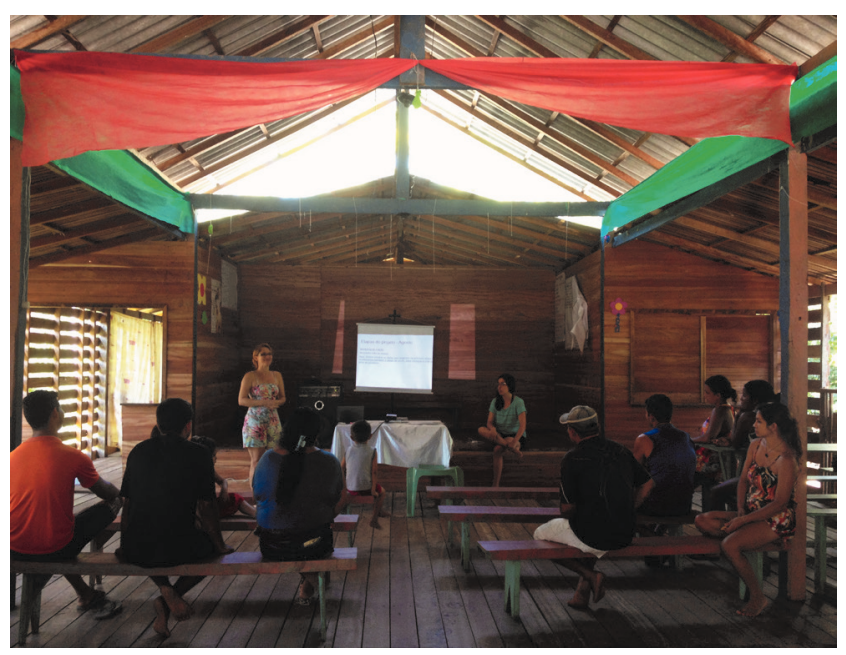

Figura 01 - Apresentação do projeto, da metodologia, dos objetivo e cronograma de trabalho para a comunidade

Fonte: Autores.

\section{CARTOGRAFIA SENSÍVEL}

A metodologia utilizada buscou reconhecer as qualidades do produto e do território, trazendo à tona as percepções do lugar através da imersão no cenário escolhido - a comunidade ribeirinha de Cristo Rei, na cidade de São Sebastião da Boa Vista, Marajó/PA - lar dos artesãos que trabalham com a tala do Jupatí. Assim, o percurso metodológico se estrutura em sete dimensões da prática, que não se excluem, mas se compõem sucessivamente, a saber:

Sentir através de uma leitura sensível dos modos de vida da comunidade, explorando os sentidos do habitat, das cenas do cotidiano, da paisagem geocultural e da vida marajoara.

Conviver com a comunidade. $O$ 'estar presente' é fundamental para a confiança e o desenvolvimento do trabalho em parceria com os artesãos, fazendo "minha casa, a sua casa".

Olhar para cada lugar de forma nova, como se fosse a primeira vez, vendo além do olhar do viajante, despertando o olhar do designer, sensível e atento, que vê em cada forma uma possibilidade de criação, inspiração e beleza.

Co-criar com os artesãos da comunidade, através de dinâmicas e workshops, onde foram acolhidas e percorridas suas memórias e relações com a vida ribeirinha. Uma vivência coletiva entre os componentes da equipe do projeto e os participantes, que gentilmente compartilharam suas histórias e lembranças como base de inspiração das peças de mobiliário.

Sistematizar as informações coletadas, as experiências vividas e as histórias ouvidas no curto espaço de tempo de imersão do coletivo no território. Através de técnicas de brainstorming, e uso de palavras-chave foram surgindo as diferentes leituras, caras ao conceito da criação das peças.

Compartilhar com os artesãos, através do workshop de criação coletiva, o conceito das linhas em seu desenvolvimento. Ouvir seus feedbacks, fazer ajustes necessários e compreender seu sentimento de pertença e representação nos traços desenhados.

Executar o conceito da linha criada, onde os produtos escolhidos serão prototipados pelos artesãos no barracão da comunidade, em uma grande oficina a céu aberto, com diversos conhecimentos e saberes dialogando sobre soluções e desafios a serem vencidos. Questões como: Qual o melhor encaixe? Será que sustenta? E se fizermos dessa forma? Alguém já tentou isso antes? E se virarmos do avesso? As possibilidades são diversas e a criatividade é testada no fazer conjunto.
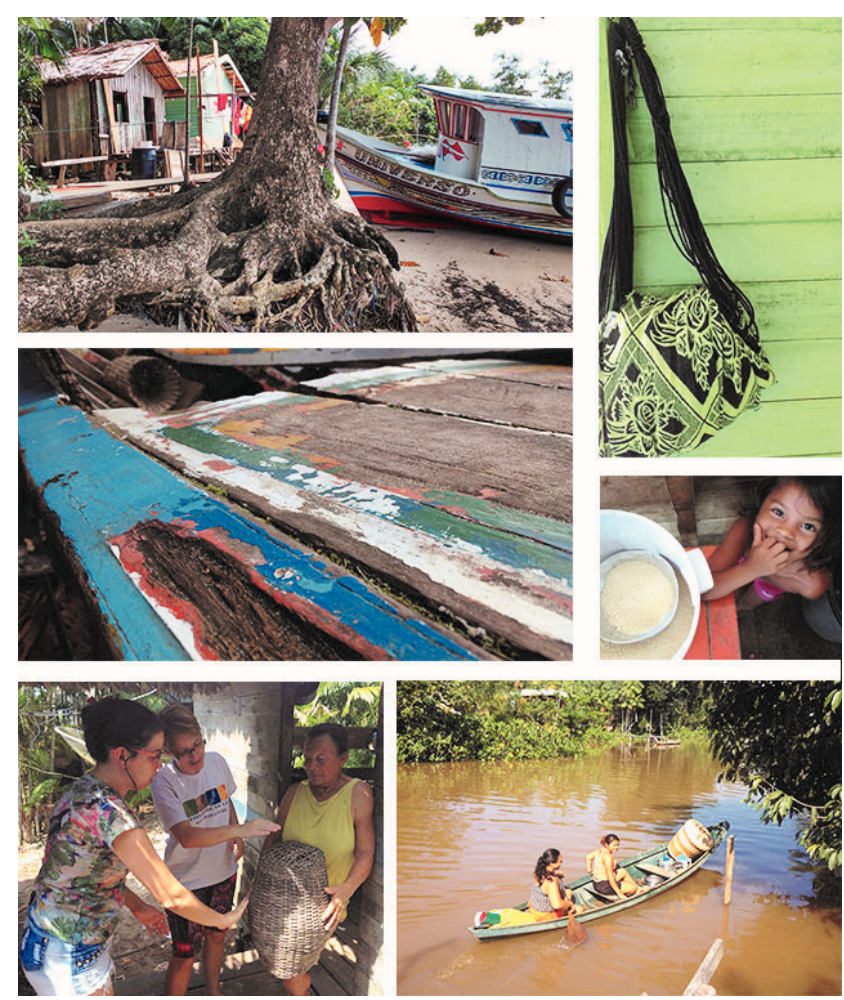

Figura 02 - Imersão no cenário, painel semântico construído a partir da vivência dos designers na comunidade

Fonte: Autores.

\subsection{Co-criação}

Em (Binder et all, 2015) são discutidas as formas pelas quais o design participativo, que tem ao longo das últimas décadas fornecido referências para compreendermos o potencial democrático da colaboração em design, pode ser revigorado através de experimentos de design democrático. À luz de um deslocamento da centralidade humana e da proeminência das práticas representacionais colaborativas, oferecidas pela tradição da teoria ator-rede, são abordadas as possibilidades de criação daquilo que os autores denominam de um parlamento de coisas e de laboratório de referências partilhadas. 
Ainda segundo Binder et al (2015), trata-se aqui de uma abordagem voltada às questões de interesse, por meio de práticas de participação em laboratórios, compreendidos como espaços onde sejam colocadas e experimentadas, de forma sempre reinventadas, as relações, trocas e participações das partes interessadas.

Ao pensarmos a atividade de co-criação do ponto de vista da atividade de design, é possível pensar o lugar do designer não como provedor de soluções isolado, mas como gestor de um projeto que envolve diferentes stakeholders para, de forma conjunta, atingirem um resultado comum, seja este um produto, um sistema ou uma linha de mobiliário. Em resumo, seria necessário para tanto, valer-se de dispositivos de conexão, que permitam que os diferentes sujeitos envolvidos nesses processos tragam para o campo de trabalho suas questões de interesse. $\mathrm{Na}$ experiência que aqui relatamos foram acionadas diferentes etapas de experimentação e abertura para trocas de saberes, iniciadas por oficina de vivência onde buscou-se materializar na construção coletiva as memórias e trajetórias dos moradores através de seus territórios afetivos.

Ao retomarmos o desenvolvimento contínuo dessa metodologia, trabalhamos inicialmente com um mapa, então proposto como substrato para inscrição das histórias de vida que serão narradas a partir de um jogo, no qual palavras lançadas por um dado temático evocam temporalidades, lugares, objetos e afetos. Inspirados pela noção de cartografia, já abordada anteriormente, e considerando esta também como um percurso metodológico para inscrição de processos e narrativas de subjetivação, buscamos na ferramenta do mapa um suporte para realizar registros das relações entre vidas e objetos ligados ao território de São Sebastião da Boa Vista.

Com o objetivo de resgatar trajetórias e com elas tornar visíveis as múltiplas relações cotidianas com mobiliários próprios daquela cultura, buscamos trazer à tona questões a partir das quais os moradores pudessem construir e partiIhar significados. As perguntas das quais partimos para tessitura dos mapas pessoais/coletivos buscam evocar, pela oralidade e pelas imagens, histórias da vida, momentos e espaços, dando corpo através do registro às fases de vida e às relações que a localidade possui para os moradores.

Qual a tua história? Quais fases formam tua vida? Em que lugares? Com quem?

Quais as coisas?

Entendendo as relações afetivas, sejam familiares ou de amizade, que envolvem os moradores da região em redes bastante densas, é proposta uma roda de conversa, trabaIhando as dinâmicas com um grupo único, a fim de que as narrativas possam se complementar, dando espaço para que se tornem visíveis as tramas que as vidas narradas partilham.

Aqui os mapas da minha vida se completam com os da tua vida...

\subsection{Dinâmica do workshop de vivências}

O jogo é apresentado inicialmente pelas facilitadoras e, convidados a sentar em roda, os participantes recebem, cada um uma folha de cartolina e acesso a lápis, canetinhas, revistas e tesouras de forma compartilhada. Com esse material são chamados a contar/desenhar suas histórias. $\mathrm{O}$ dado é proposto como dispositivo "anti-silêncio", para disparar conversas e narrativas, a fim de superarmos juntos as dificuldades iniciais em começar a falar. $O$ dado possui em suas seis faces cinco palavras-tema e uma palavra coringa. As palavras-chave servem como gatilhos para que sejam recuperados aspectos das trajetórias dos participantes, que possam ter sido esquecidos ao longo da atividade. Nesse sentido, palavras como infância e família nos ajudam a trazer para a roda (e para os papéis) acontecimentos, ambiências e relações cotidianas que dão conta de momentos diverso da vida que tomam lugar nesses espaços. A face coringa é utilizada para que os participantes sugerissem temas ou aspectos não abordados ou não considerados inicialmente $\mathrm{e}$ que julguem relevantes para narrativa de suas trajetórias.

Jogo das vidas: minha e nossas, individual e coletivo

Os participantes lançam o dado alternadamente, de acordo com a ordem da roda. Ainda que cada participante lance individualmente o dado, a cada palavra todos partilham histórias ligadas ao tema sorteado, seja falando para a roda, seja fazendo seus desenhos e colagens no papel. As palavras-chave foram pré-definidas tendo por base um conhecimento prévio sobre os modos de vida marajoara, buscando visibilizar temáticas caras às populações ribeirinhas de forma geral e cotidianas aos moradores do território em particular, a saber: família, infância, natureza, alimento/comida, trabalho/fazeres. O jogo se desenvolve até que todos os envolvidos considerem que representaram de forma satisfatória aquilo que desejavam registrar. Aqui assinalamos que podem ser feitas duas ou mais rodadas com todos podendo lançar o dado.

\subsection{Olhares e registros}

Ao longo da dinâmica são registrados os processos, tanto através de vídeo e gravação de voz, quanto através de anotações que permitem assinalar impressões dos facilitadores sobre o jogo, o grupo e o ambiente de forma geral. Registros esses retomados na atividade de sistematização que sucede a oficina de vivências. 
Ao final da atividade todos puderam apresentar seus mapas. Houve a oportunidade das facilitadoras evidenciarem semelhanças e complementariedades entre os mapas dos participantes. A posteriori foi montado mosai$\cos /$ varal a partir da composição dos diferentes mapas.

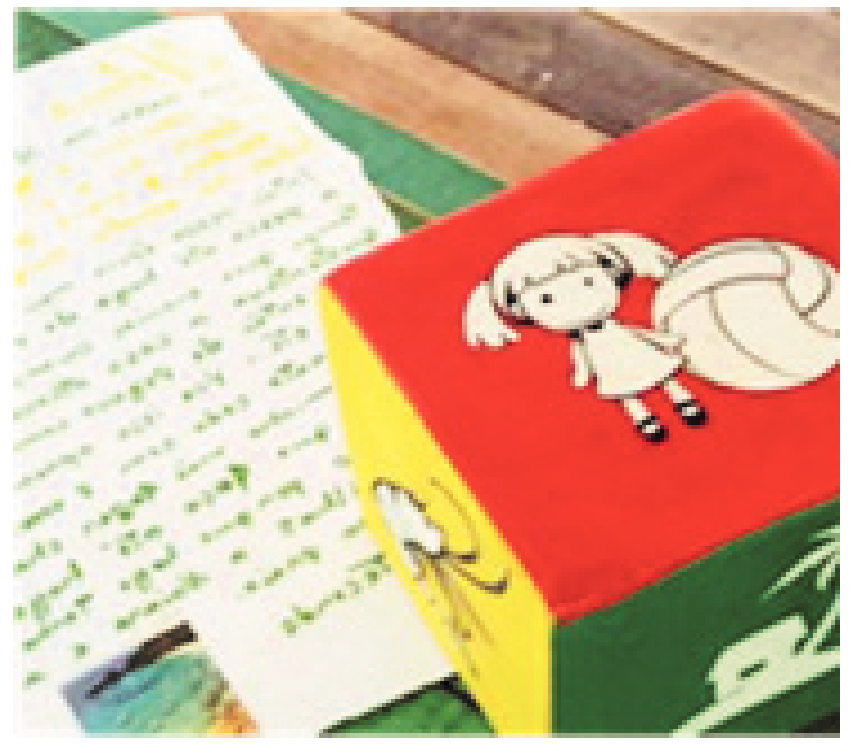

Figura 03 - Dado do jogo, onde cada face corresponde a um tema a ser compartilhado (família, infância, natureza, alimento/comida, trabalho) Fonte: Autores.
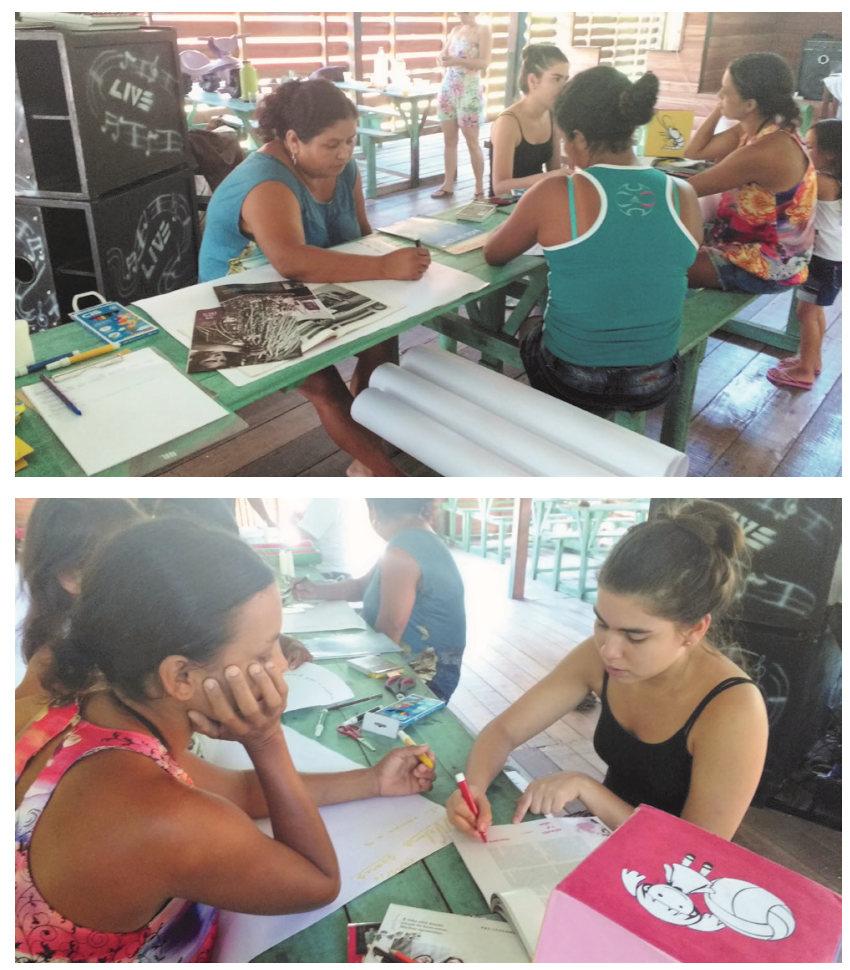

Figura 04 - Bate papo sobre o dia a dia, as lembranças, o modo de viver da comunidade, que serviu de orientação e inspiração para a criação do conceito da coleção Fonte: Autores.

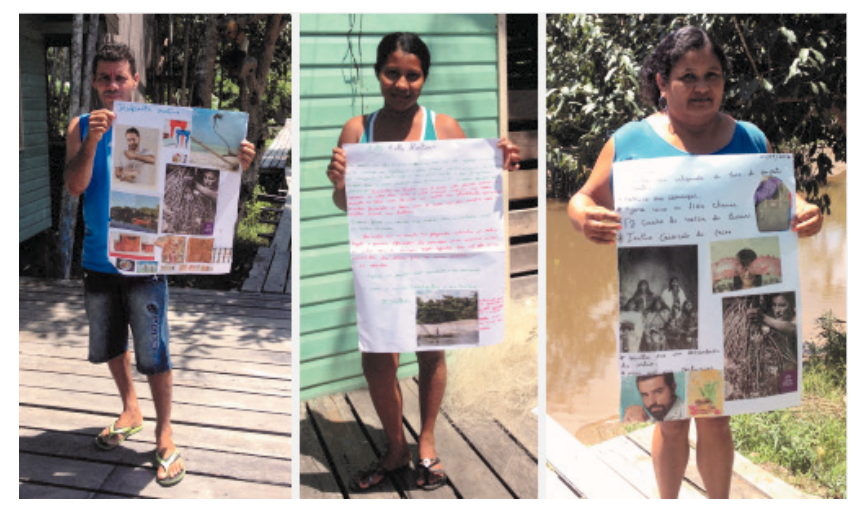

Figura 05 - Workshop de vivências, construção dos mapas Fonte: Autores.

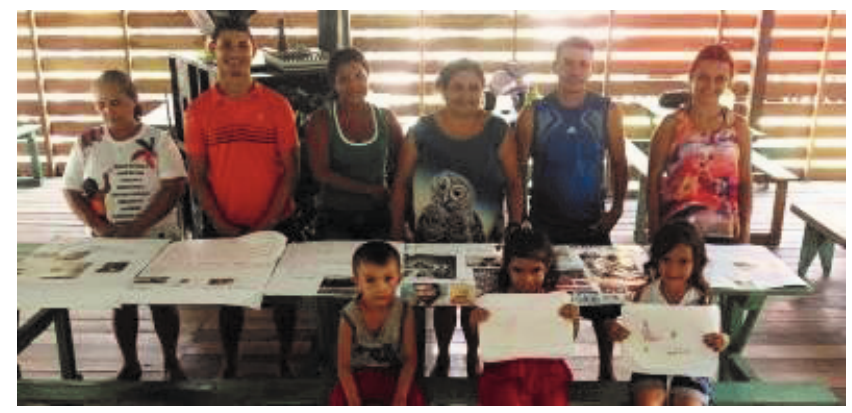

Figura 06 - Resultado da dinâmica workshop de vivências Fonte: Autores.

\section{SISTEMATIZAÇÃO}

As informações coletadas, as experiências vividas e as tornaram subsídio para o capital identitário dos conceitos das linhas de mobiliários em Jupatí. O ponto de partida para o processo construtivo foi captar quais aspectos simbólicos representariam mais fielmente o território e as lembranças da comunidade. Nesse sentido, a metodologia trazida por Kruken (2009) contribuiu decisivamente ao elencar oito ações para potencializar produtos locais.

A equipe, então, realizou a sistematização de registros, cartazes, anotações e fotografias produzidos ao longo do workshop de vivências. Cada depoimento foi revivido atendo-se aos principais temas, objetos e dinâmicas abordados nas narrativas durante a primeira etapa deste projeto.

O grupo de designers se debruçou sobre os mapas da vida de cada participante, sistematizando as informações coletadas de acordo com as orientações da metodologia de Niemeyer "[...] quando se quer comunicar algo, seja a identidade de uma empresa, uma campanha de saúde pública, um evento, temos que considerar que este algo já tem uma personalidade. " (NIEMEYER, 2009, p. 64).

Nesse sentido, as palavras presentes nessas cartografias sensíveis permitiram encontrar pontos comuns e 
trajetórias de pertencimento à comunidade do Cristo Rei. Ao imergirem novamente no universo da comunidade, revivendo falas, sentimentos e lembranças a equipe de designers inicia o brainstorming, listando as palavras que vierem à mente de cada integrante, referentes à temática do projeto, de acordo com as orientações de Lucy Niemeyer:

As etapas da estratégia consistem geralmente de enunciados, relativamente genéricos, que devem, de início, ser decompostos em suas diferentes partes. Esta decomposição se faz segundo a técnica de brainstorming, ao longo da qual os componentes são classificados segundo a sua importância para o conceito total. (NIEMEYER, 2009, p. 64)

Concluído o brainstorming, "os termos selecionados serão analisados e a equipe fará sucessivas eliminações até chegar a uma síntese: três ou quatro palavras, que então serão escritas em cartões". (NIEMEYER, 2009, p. 67). Identificadas as palavras-chave, "[...] sobre uma mesa coberta com papel em branco são espalhados recortes de imagens. [...] Deve haver a preocupação de garantir que seja reduzido o caráter figurativo dos recortes: imagens em que haja predomínio de cores, texturas, linhas, formas abstratas" (NIEMEYER, 2009, p. 67). A partir daí, Niemeyer aponta que "[...] de posse da síntese feita, o designer tem um balizamento para a construção do enunciado a que se propõe, seja ele de que natureza for" (NIEMEYER, 2009, p. 68).

Através desses direcionamentos, as temporalidades Origens, Movimentos e Futuro surgiram como conceitos capazes de abarcar as três principais dinâmicas presentes na história da comunidade e das pessoas daquele lugar, captados a partir do encontro.
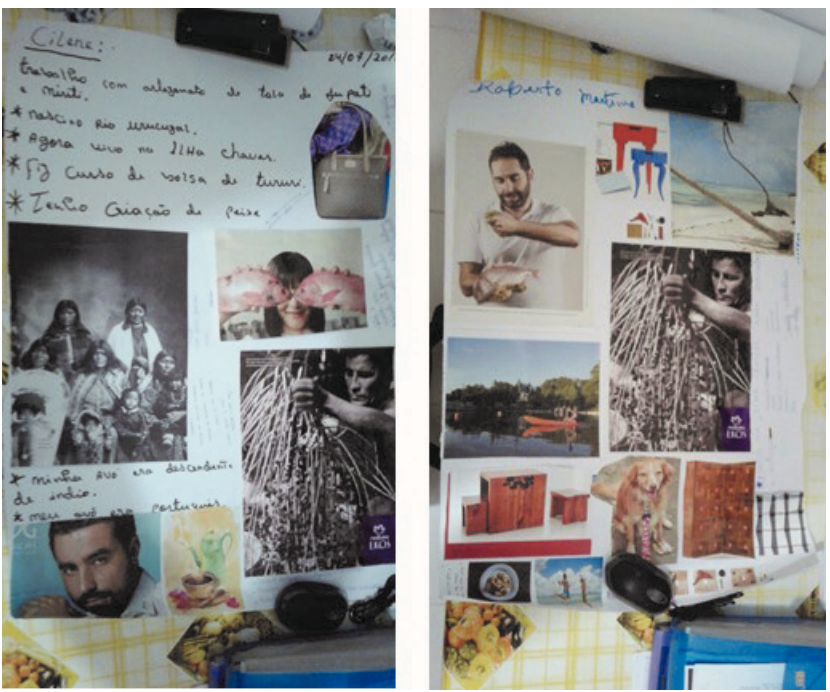

Figura 07 - Construção do Painel Semântico através da análise dos mapas, palavras-chave e fala dos participantes do workshop Fonte: Autores.
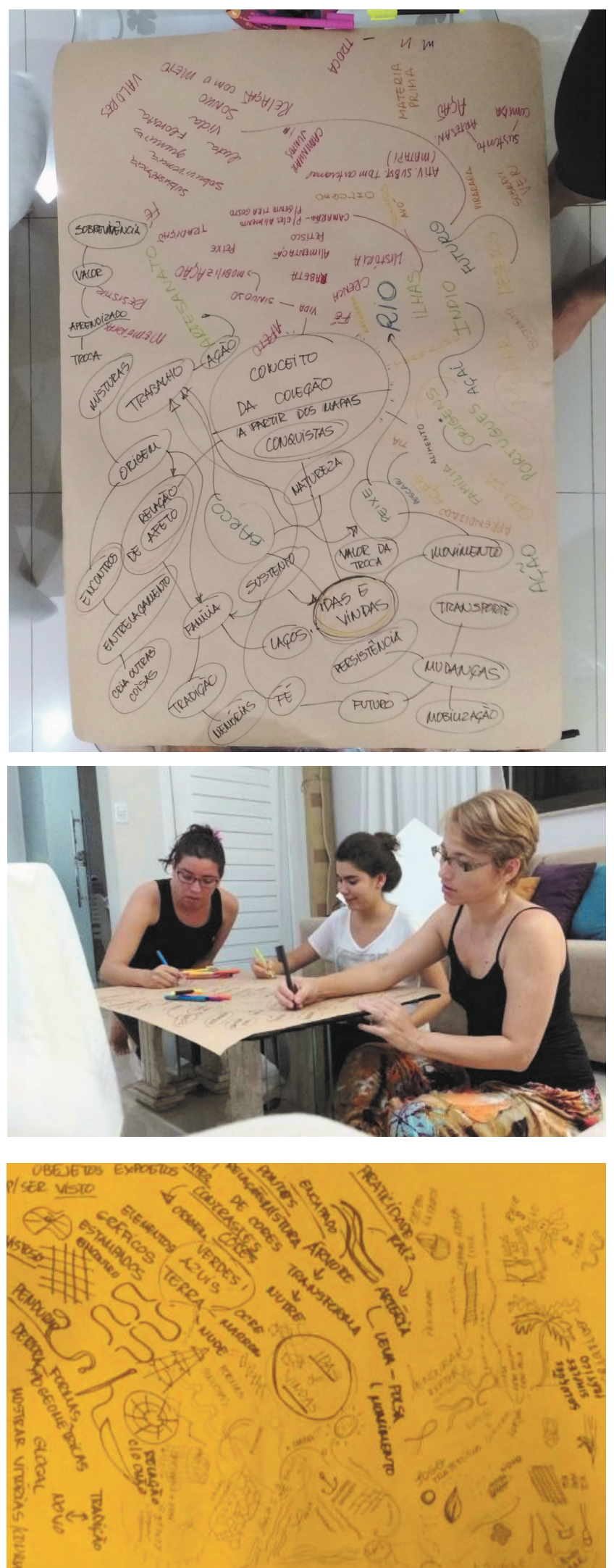

Figura 08 - Sistematização, Brainstorm.

Fonte: Autores. 


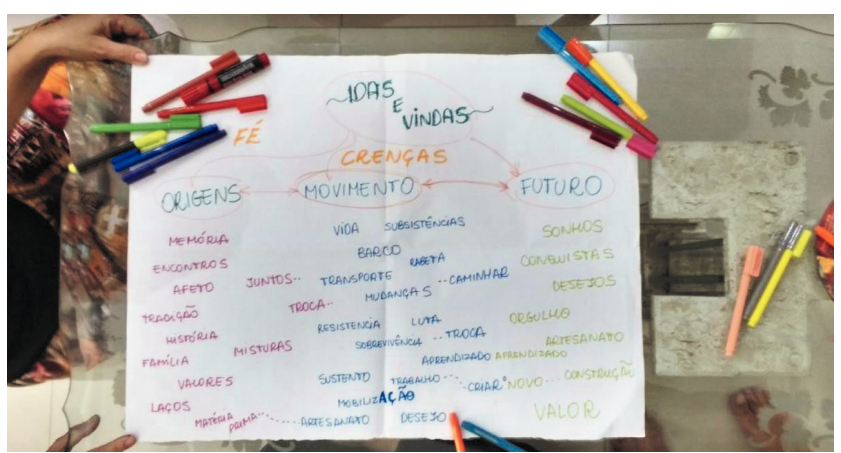

Figura 09 - Sistematização, Linha de produtos Fonte: Autores.
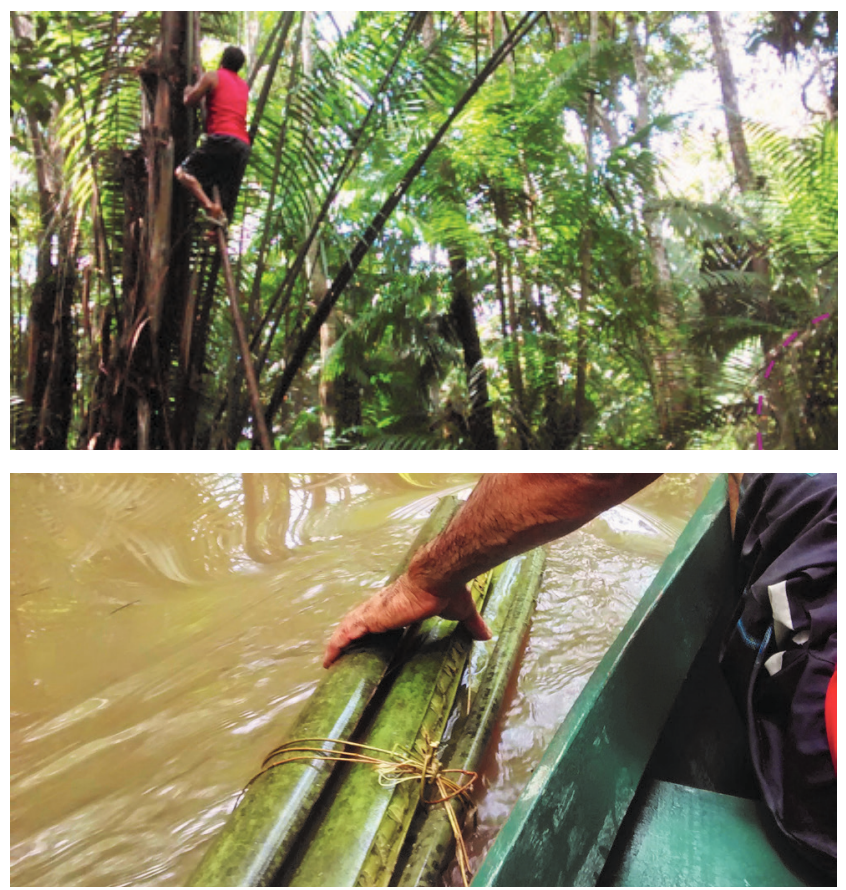

Figura 10 - Retirada da palma do jupatí e transporte do caule da palmeira Fonte: Autores.

\section{MOBILIÁRIO EM JUPATI}

Após a sistematização das experiências, movimentos e ambiências, a etapa final do Projeto Cotidianidades caminhou para o processo de criação coletiva dos modelos que compõem a linha de mobiliários. Como objetivo, encontrava-se fazer dos produtos vetores de histórias e movimentos, desejos e caminhos, objetos que narrassem fragmentos do cotidiano gravado, registrado e revisitado nas etapas anteriores. $\mathrm{O}$ momento dedicado à criação coletiva, destina-se a ativar as competências tradicionalmente presentes no território, materializando novos objetos e artefatos na interface dos saberes dos artesãos com o campo do design. Foram apresentados os conceitos utilizados para dar nome a três movimentos principais presentes nas narrativas e espaços visitados durante 0 workshop de vivências.

\subsection{A matéria-prima}

A característica da produção artesanal tradicional do município de São Sebastião da Boa Vista, no arquipélago do Marajó, está na utilização do jupatí (Raphia Taedigera), palmeira de pouca altura, mas de folhas compridas, com uso variado. Da tala mais grossa faz-se o matapí, utensílio usado pelos ribeirinhos na pesca artesanal do camarão, e o parí, espécie de esteira utilizada para tapar o igarapé na maré cheia servindo de armadilha para prender os peixes que na vazante não conseguem sair por conta a colocação do parí; da tala mais fina faz-se cestos, baús em vários tamanhos e formas.

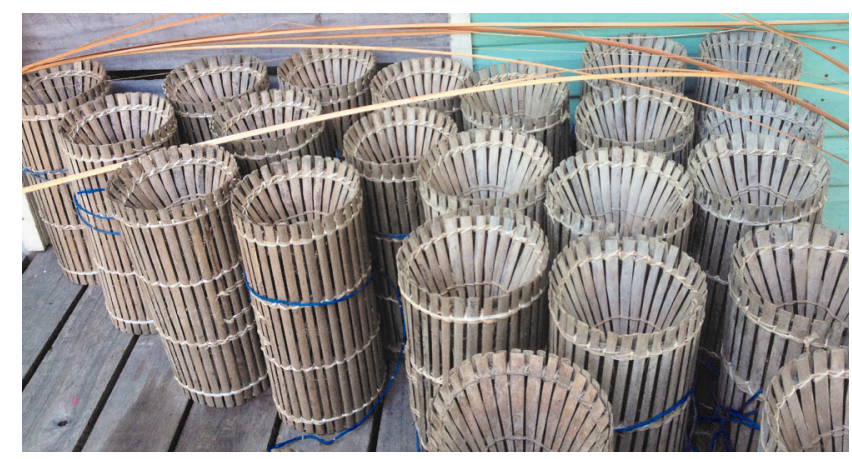

Figura 11 - Matapí, utensílio para pesca do camarão

Fonte: Autores.

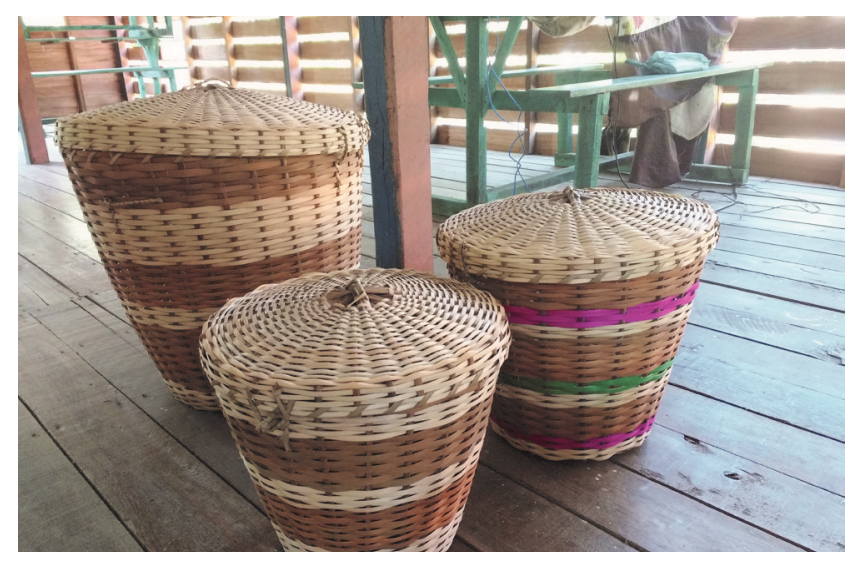

Figura 12 - Baú feitos com tala de jupatí Fonte: Autores.

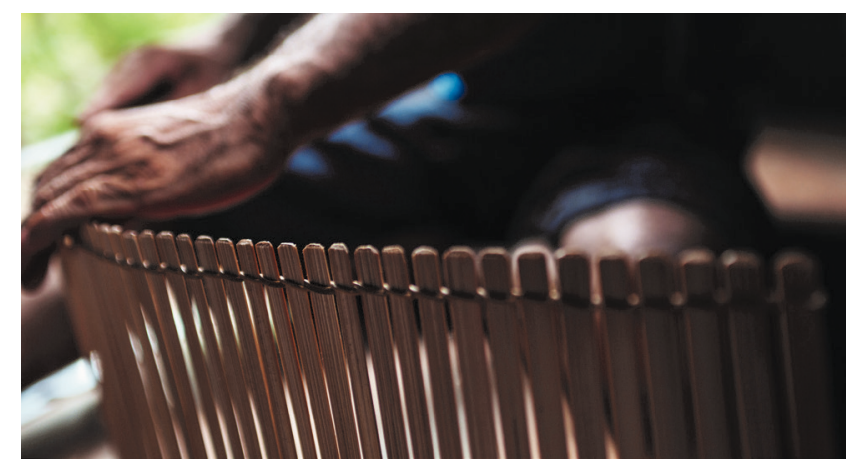

Figura 13 - Pari, esteira utilizada para 'tapar' igarapé na maré cheia, servindo de armadilha para prender os peixes

Fonte: Autores. 


\subsection{Criação Coletiva}

Construídos pelos participantes ao longo do workshop de vivências, os painéis de referência foram dispostos no barracão.

Cercados pelas referências e histórias uns dos outros, o grupo pôde retomar elementos em um processo que ativava as competências e técnicas próprias do território, para o desdobramento em novos modos de dar forma às talas do jupati. A partir das conversas a equipe pôde passar dos conceitos às ideias, encontrando na fala dos participantes as palavras que complementavam as imagens $\mathrm{e}$ referências de produtos.

A partir dos croquis esboçados pelos facilitadores, os artesãos orientaram a criação dos modelos, partilhando saberes e soluções no uso da tala. Partindo da análise dos croquis, foram sendo definidas conjuntamente, numa relação material entre designer e artesãos, as técnicas, materiais e estruturas que dão corpo à linha de mobiliário.

As linhas desenvolvidas se definem em suas relações com o cotidiano e seguem três temporalidades: Origem,

\section{Movimento e Futuro.}
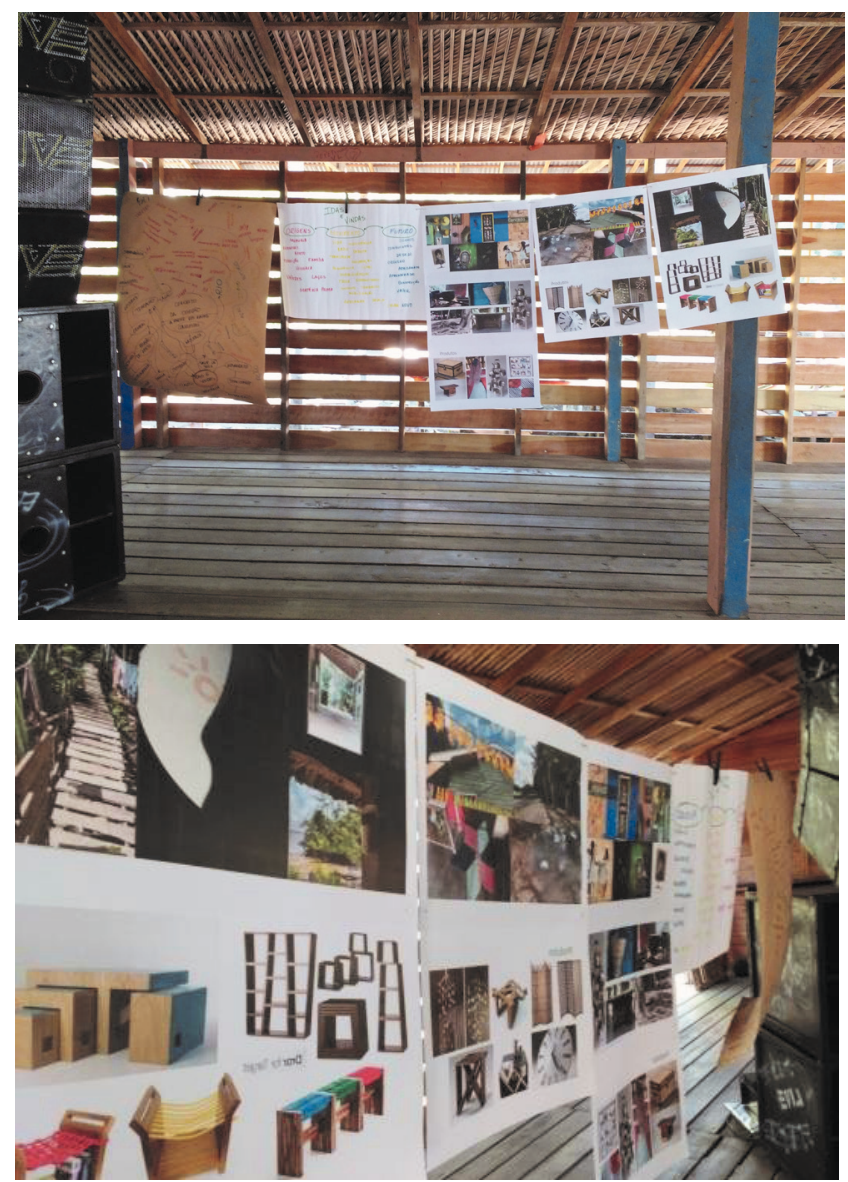

Figura 14 - Criação coletiva, Mapas de vida e painéis de referência Fonte: Autores.

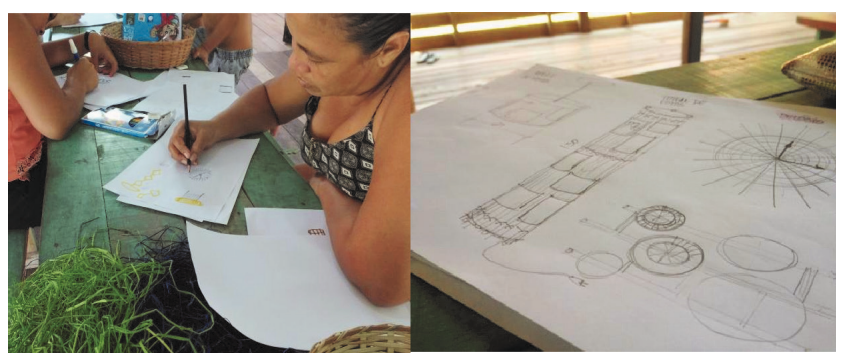

Figura 15 - Criação coletiva, elaboração dos croquis Fonte: Autores.

\subsection{Prototipagem}

Nesta última fase a culminância de todo o trabalho se materializou em uma oficina final com duração de 5 dias, em que participaram designers e artesãos e aonde estes puderam colocar em prática seus conhecimentos de forma nova. A partir dos croquis desenvolvidos no workshop de criação coletiva, os artesãos foram testados a fazer produtos diferentes, com estruturas diversificadas que os desafiaram a ver e a trabalhar a matéria prima de forma nova. As soluções encontradas para cada protótipo misturavam antigos saberes trazidos pelos artesãos para as peças (como a amarração com punho de rede empregada na Prateleira Maresia), bem como o desenvolvimento de novos arranjos e técnicas.

Ao longo do trabalho de confecção o envolvimento dos artesãos pode ser percebido na execução das peças e além. A identificação perpassou um sentido de representação desempenhado pelas peças, tendo muitos deles demonstrado interesse em reproduzi-las para uso em suas casas e espaços coletivos.

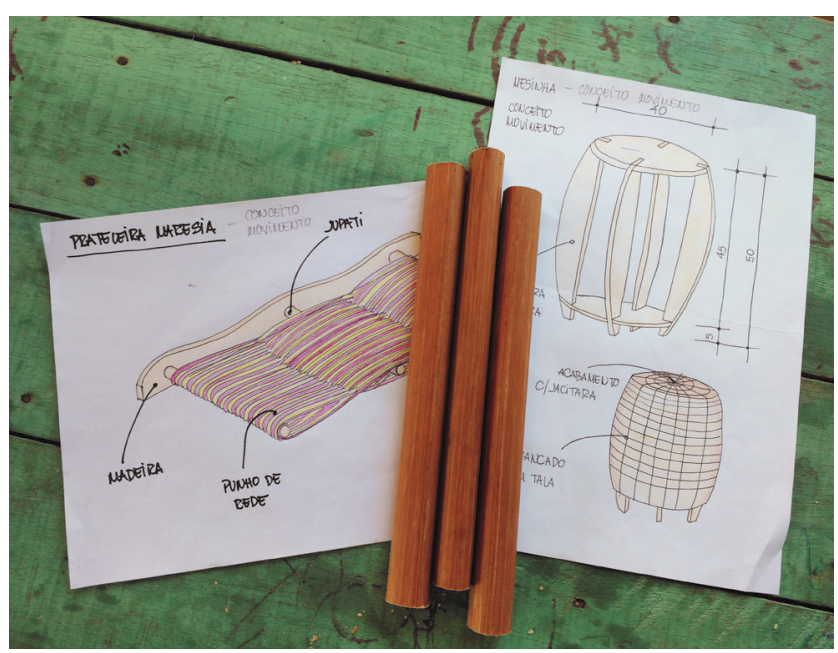




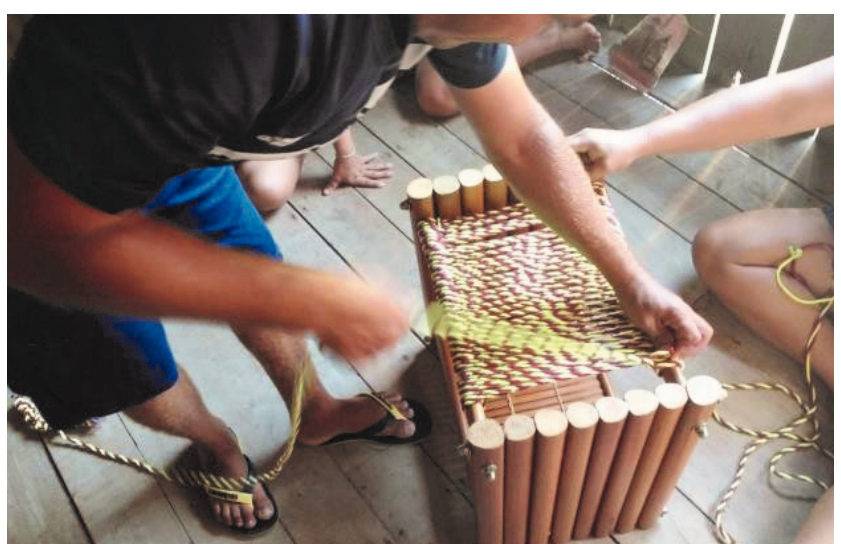

Figura 16 - Prototipagem, materialização dos croquis Fonte: Autores.
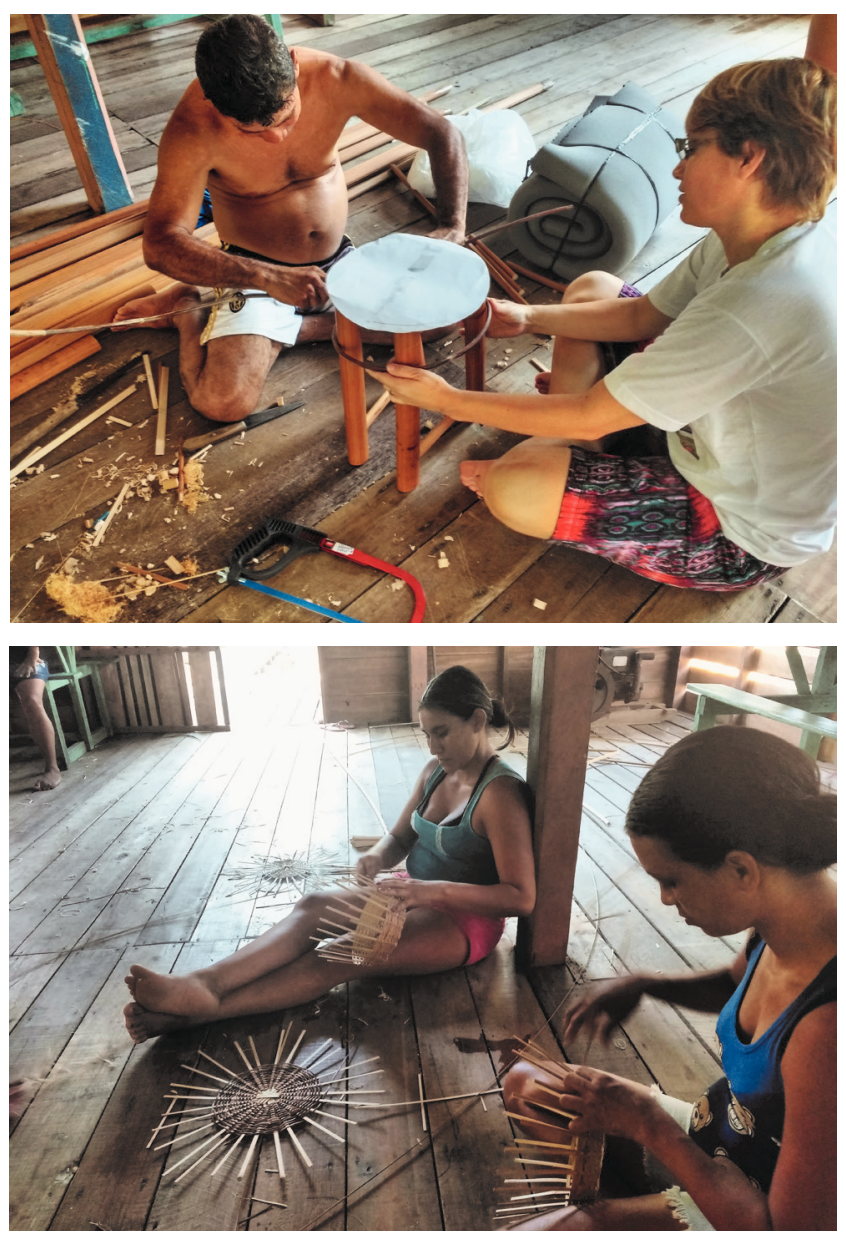

Figura 17 - Prototipagem, artesãos e designers em meio ao processo de criação das peças Fonte: Autores.

\subsubsection{Temporalidades ribeirinhas}

Como um entrelaçamento do tempo, o mobiliário resultante do processo de criação coletiva evoca distintas temporalidades em um percurso que narra em 12 peças a história, os movimentos e sonhos da comunidade do Cristo Rei, em São Sebastião da Boa Vista, Pará. Imergir no ritmo da vida ribeirinha possibilitou o vínculo necessário para a materialização coletiva de um rico universo de modos de vida. Modos muito próprios de narrar, comer, cuidar e mover- se; percursos em que se constrói a vida cotidianamente entre as águas do rio. Aquilo compreendido então como cotidiano revelou uma relação de idas e vindas, através do tempo. Relação que se desdobra em uma trama que envolve o passado, lugar das origens e tradições; o presente, repleto de movimentos, lutas e transformações; e o futuro, com tudo o que é sonhado e projetado para o amanhã. $O$ cotidiano ribeirinho é lugar onde vivem tempos diversos, onde visitamos em cada cômodo, em cada objeto e narrativa as muitas camadas e caminhos que trouxeram até aqui famílias e seus costumes, comunidades e suas lutas, artesãos e seus desejos.

\section{RESULTADOS}

\subsection{Linha de produtos}

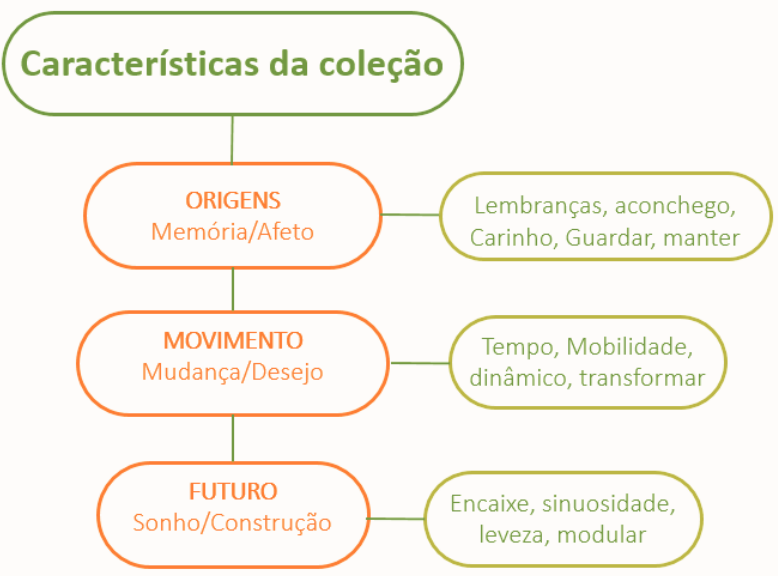

Figura 18 - Sistematização, Linha de produtos Fonte: Acervo da pesquisa (2016).

\subsubsection{Linha Origens}

As histórias de vida narradas pelos moradores e pelos objetos tornam visível a presença de elementos do passado no cotidiano ribeirinho. A temporalidade das origens traz em suas peças os inícios e costumes que transportam tradições através do tempo. As idas e vindas pelos rios que fazem encontrar. Os encontros que fazem parte da história do lugar. Múltiplas origens que constituem a comunidade e revelam formas, de vida e materiais, há muito ensinadas. $O$ hábito de sentar no mocho próximo ao chão enquanto se tece, as baterias onde estão penduradas as louças, como faziam as avós, o modo de dispor os utensílios na cozinha ao alcance das mãos e dos olhos. Essas referências, através dos elementos apreendidos na pesquisa cartográfica, dão origem a objetos cujas formas são vetores de memórias afetivas. 


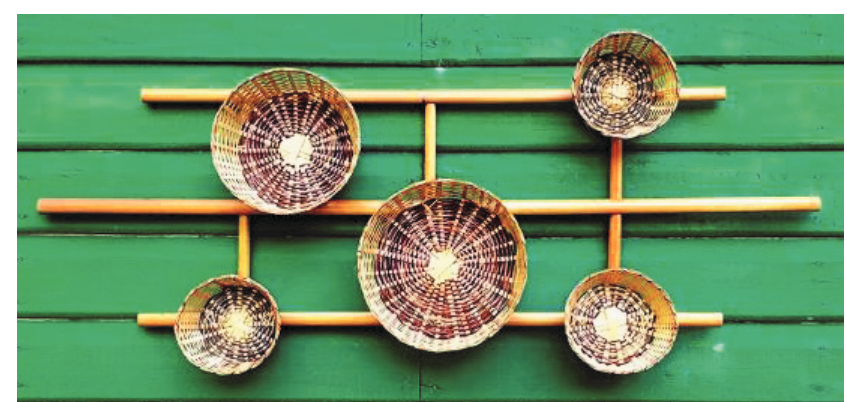

Figura 19 - Linha Origens, Painel Giral Fonte: Autores.

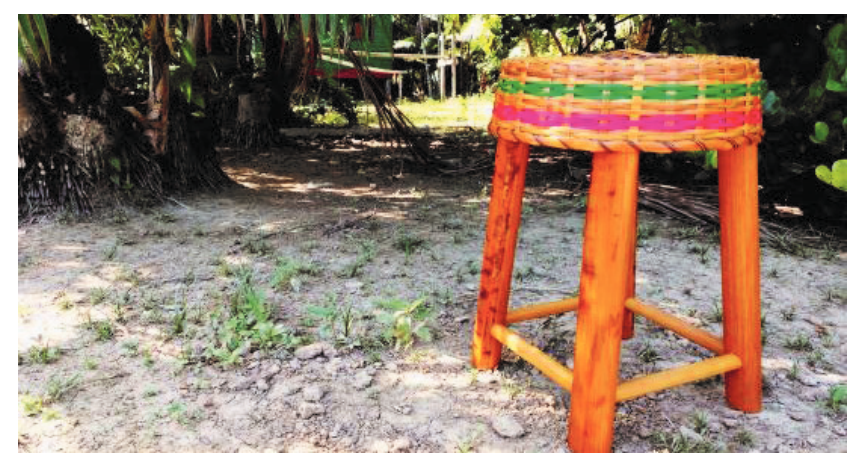

Figura 20 - Linha Origens, Mocho

Fonte: Autores.

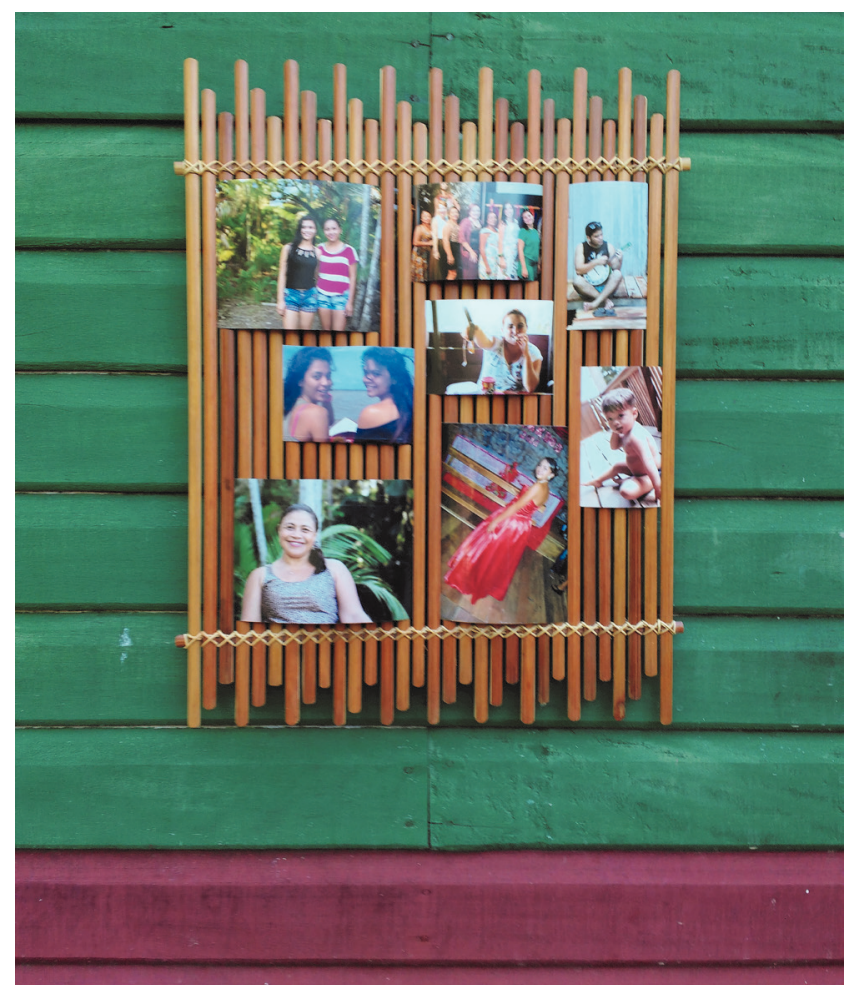

Figura 21 - Linha Origens, Painel de memórias Fonte: Autores.
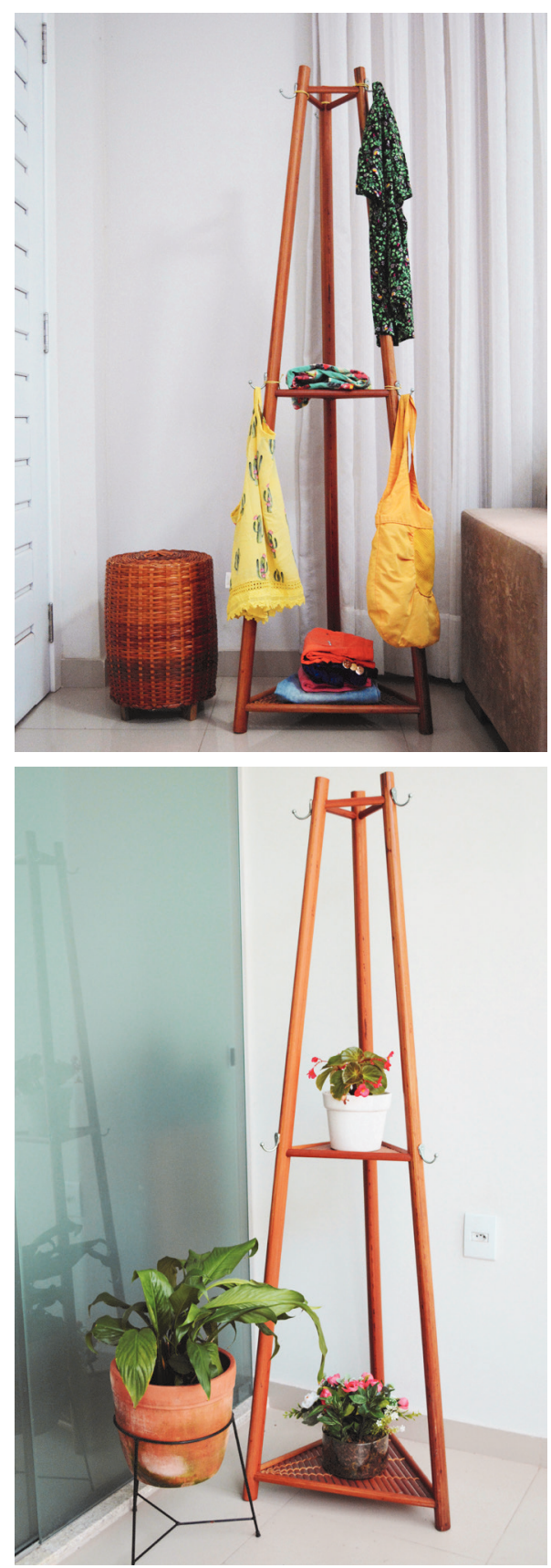

Figura 22 - Linha Origens - Cabideiro Bateria Fonte: Autores.

\subsubsection{Linha Movimento}

A vida à beira do rio é movimento. Seja nos barcos e rabetas, seja nas lutas cotidianas por sobrevivência ou na busca por mudanças e transformação da realidade. Os movimentos, de trabalho e resistência, de organização pela valorização do artesanato, são parte significativa da vida da comunidade e inspiraram a segunda temporalidade representada em peças dinâmicas. É esse movimento que também está a valorização da troca e a busca por mais aprendizado dentro e fora da comunidade. Do encontro e do balanço fez-se um fluido objeto maresia, das técnicas tradicionais novas 
formas de dispor os cestos, através da tala do jupati se desenhou a passagem do tempo, traduções daquilo que move de sol a sol. Aqui as dinâmicas do cotidiano são reinvenções, traduzidas no desejo de fazer do artesanato, sua história, a ponte para a criação de novas trajetórias.
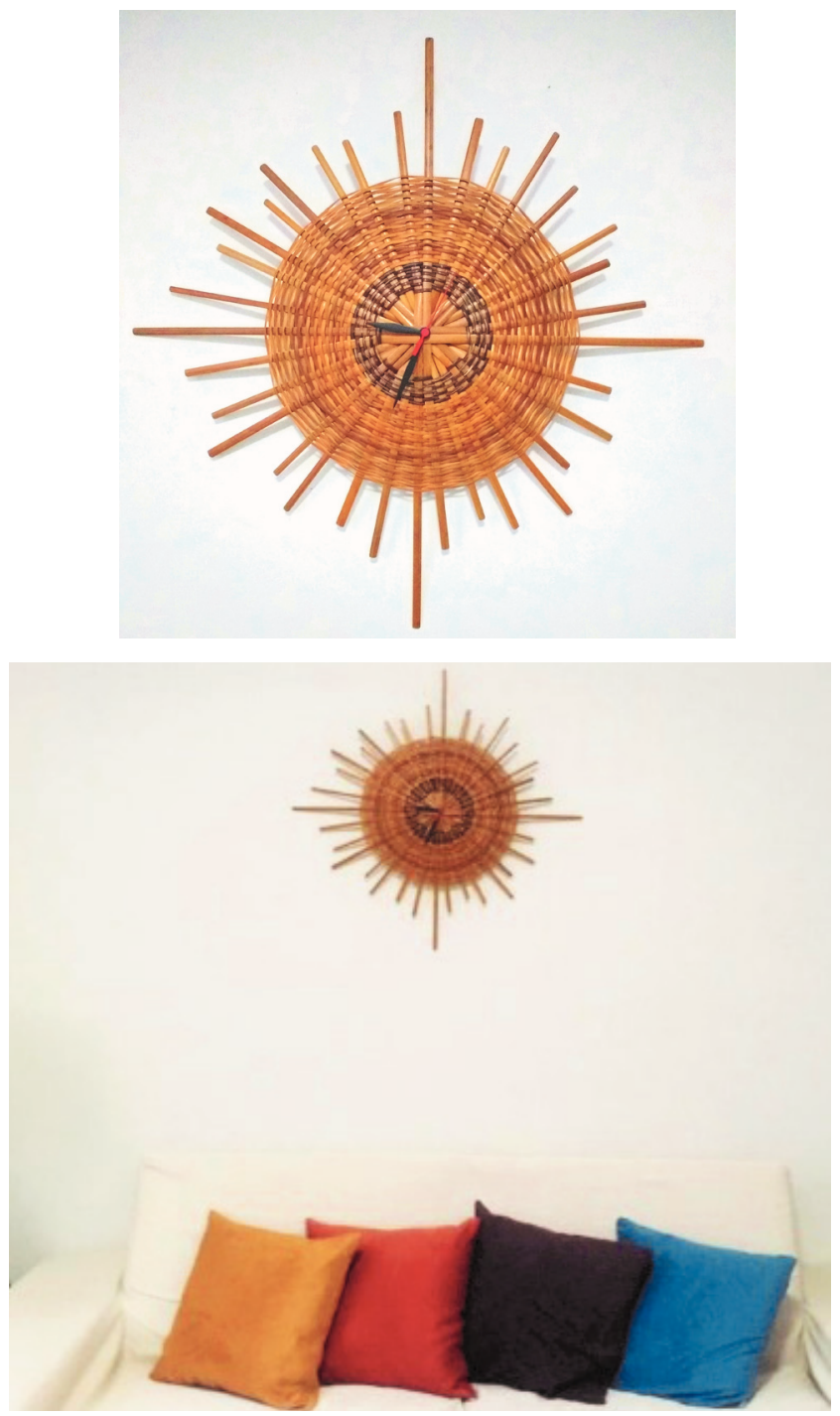

Figura 23 - Linha Movimento (relógio pôr-do-sol)

Fonte: Autores.

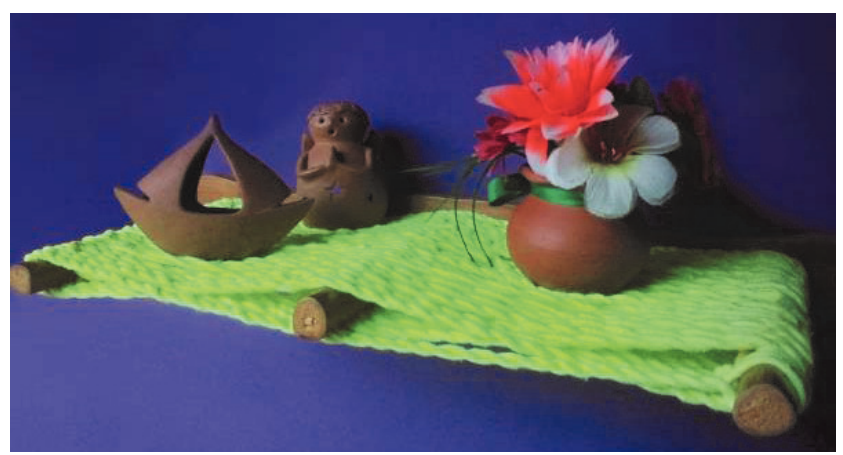

Figura 24 - Linha Movimento, prateleira Maresia Fonte: Autores.
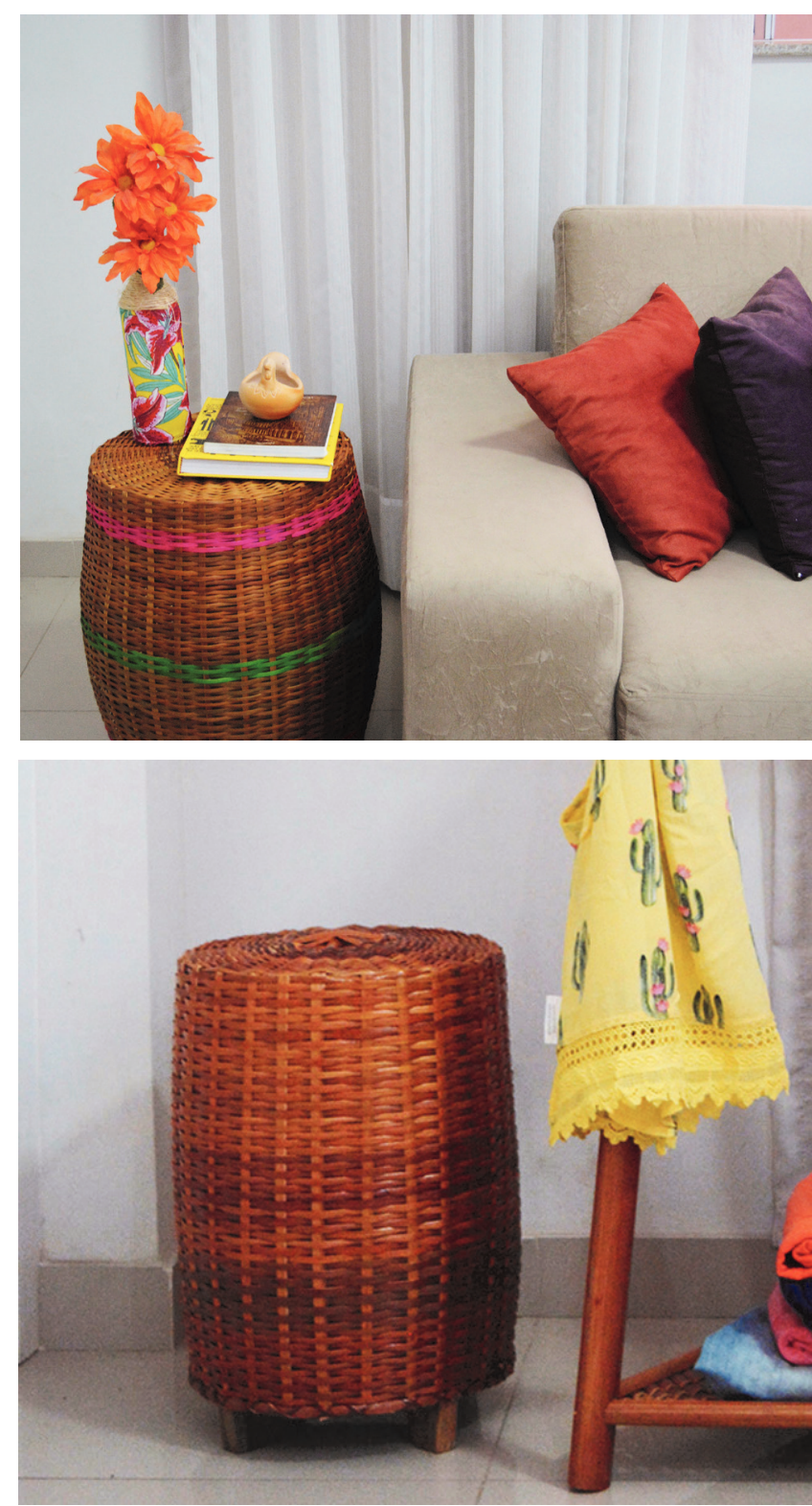

Figura 25 - Linha Movimento - mesinha e puff trama, respectivamente Fonte: Autores.

\subsubsection{Linha Futuro}

No cotidiano ribeirinho as matérias prima da floresta são material de criação da vida. Invenções e soluções criativas próprias das comunidades que convivem de forma íntima com os frutos, fibras e materiais naturais. O trabalho com a tala do jupati faz parte da tradição da comunidade e seu desejo de fazer desse material a matéria de seu futuro permitiu que compartilhassem no processo de co-criação diferentes usos potenciais. O olhar para a própria trajetória de modo novo possibilitou abordar o jupati como elemento dinâmico inspirando a concepção de peças modulares, leves e versáteis. A banqueta e os nichos encaixáveis, os pufes que se completam. Objetos produzidos como blocos de sonhos, onde as conquistas são vistas como resultado do trabalho artesanal valorizado. Como 
transformação da matéria prima e possibilidade de renda, autonomia e transformação, as peças dessa temporalidade carregam o olhar para a construção do próprio futuro.

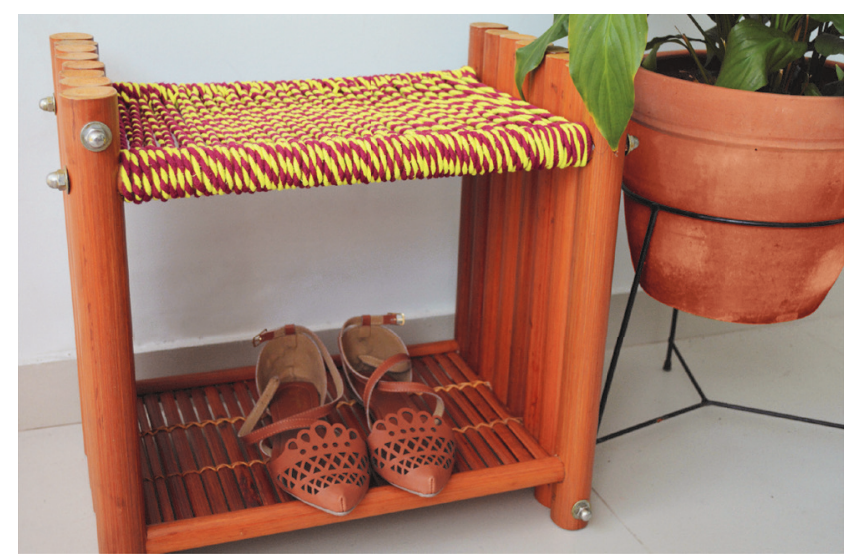

Figura 26 - Linha Futuro - Banqueta Fonte: Autores.

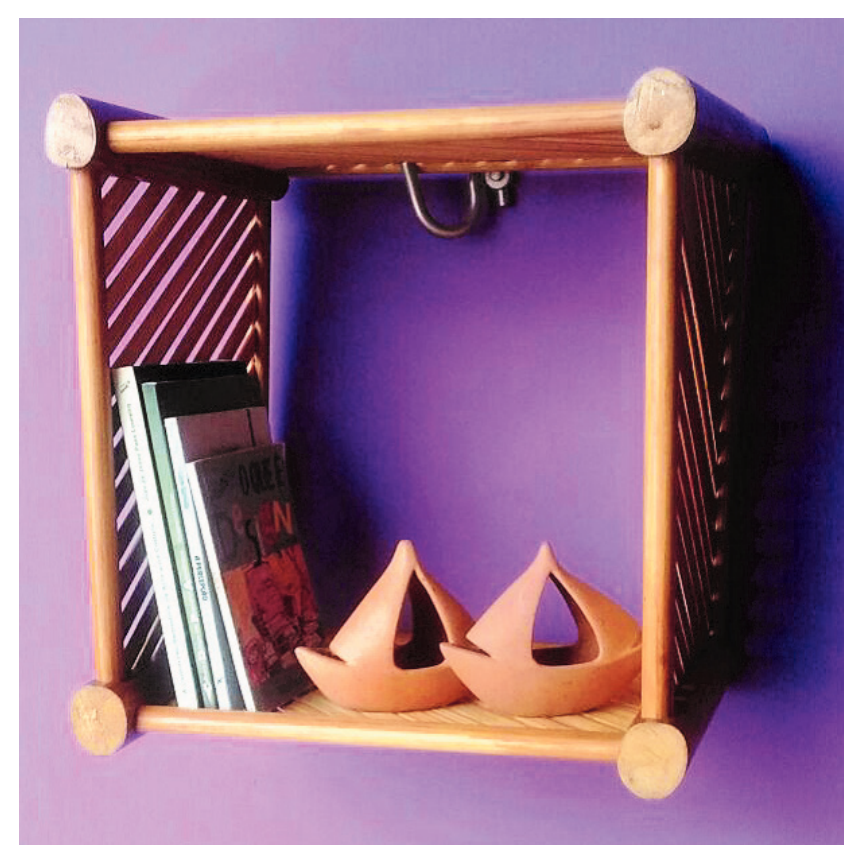

Figura 27 - Linha Futuro - Nicho

Fonte: Autores.

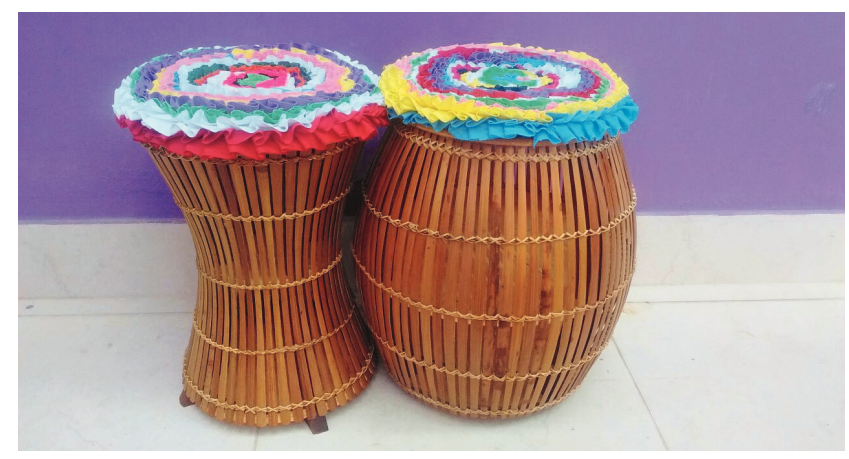

Figura 28 - Linha Futuro - Puff Retalhos Fonte: Autores.

\subsubsection{Exposição Entre Idas e Vindas}

Todo esse processo resultou na exposição "Entre idas e vindas, exposição de móveis em Jupatí", no Instituto de Artes do Pará.

A exposição contemplou os resultados satisfatórios do Edital Prêmio experimentação, Pesquisa e Difusão Artística 2016, da Fundação Cultural do Pará.

A exposição propôs resgatar trajetórias, lembranças e vivências através de mobiliários e técnicas artesãs próprios da cultura local. O cenário escolhido foi a comunidade ribeirinha de Cristo Rei, na cidade de São Sebastião da Boa Vista, Marajó/ PA: lar dos artesãos que trabalham com a tala do Jupatí.

O resultado é a coleção de mobiliário intitulada "Entre Idas e Vindas", que remete não só ao movimento dos rios que regem a vida do lugar como também as relações interpessoais que fizeram com que a comunidade surgisse e se desenvolvesse. Encontros, caminhos, lembranças e vivências contadas através de 3 linhas de produtos que foram desenvolvidas em um processo de co-criação, buscando aproveitar ao máximo a matéria prima utilizada e desafiando os artesãos a trabalhar o material de forma nunca antes feita.
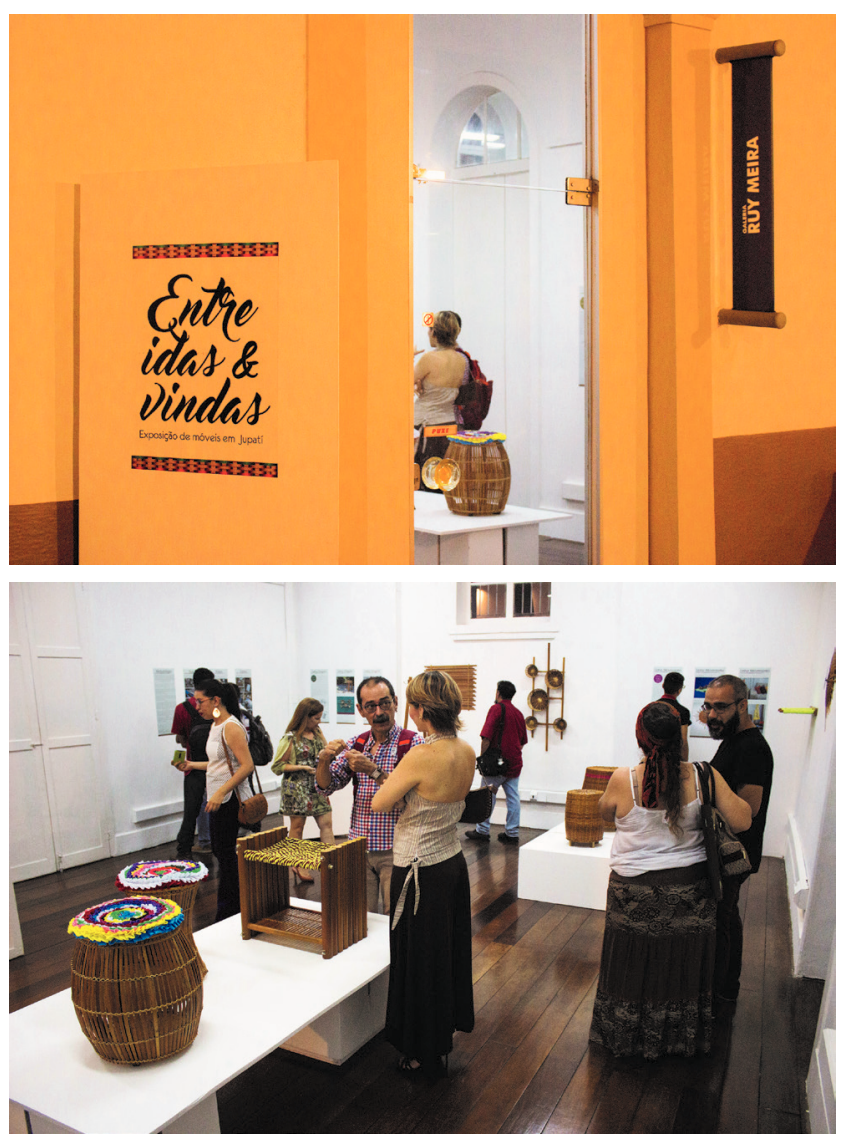

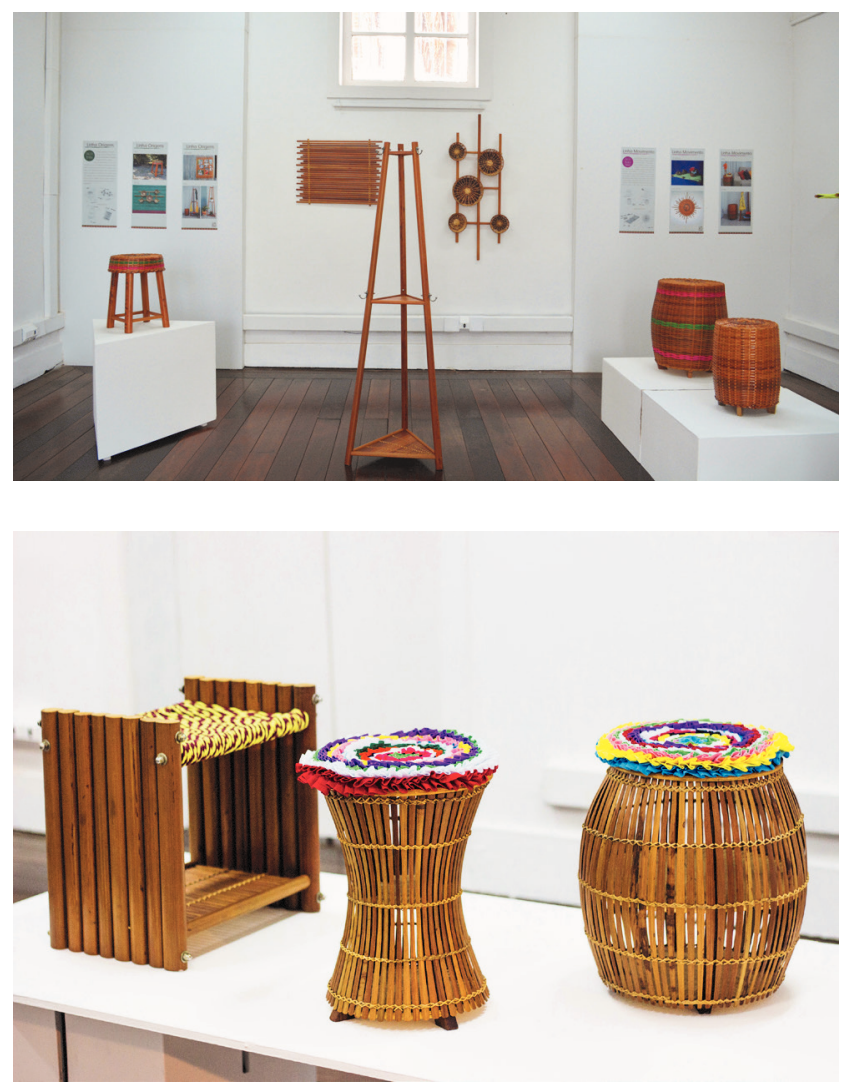

Figura 29 - Exposição dos produtos no Instituto de Artes do Pará Fonte: Diogo Vianna.

\section{CONSIDERAÇÕES FINAIS}

O trabalho desenvolvido na comunidade Cristo Rei, na cidade de São Sebastião da Boa Vista, no estado do Pará possibilitou, através de um percurso metodológico cartográfico e de uma prática projetual coletiva, a concretização de uma linha de mobiliário investida pelo saber tradicional e técnico experimentados de forma conjunta. Este percurso de desenvolvimento reforçou para o grupo de designers e também para a comunidade de artesãos o entendimento do saber fazer artesanal como parte da memória cultural daquela comunidade, uma vez que, através das dinâmicas e workshops, foi possível revisitar técnicas e processos ancestrais e acessar memórias coletivas caras aos participantes e que serviram de referência para a coleção criada.

O projeto também reforçou o processo de experimentação da metodologia de co-criação em desenvolvimento, que visa trabalhar dispositivos de conexão com a comunidade através da imersão no território, visibilizando seus interlocutores e estreitando os laços entre artesãos e designers. Compreende-se que esta metodologia ainda deve ser desenvolvida, uma vez que cada exercício de co-design e procedimento das etapas aqui apresentadas, levará não somente a melhor compreensão e melhores resultados do processo, mas também seu próprio aprimoramento enquanto prática projetual. O exercício ora apresentado guarda as particularidades da execução possível a este grupo, o que deve ser experenciado com diferentes percursos e resultados por cada grupo de designers e, sobretudo, em cada território, com seus saberes e fazeres particulares. Considera-se que o percurso que deu origem a esta linha de mobiliário possa possibilita outros processos de co-design onde os atributos de produtos guardem não apenas na forma, mas no seu modo de projetar e produzir as práticas e significados de cada território. Essa função comunicativa excede a mera superfície dos produtos e passa a compor toda a história de concepção das linhas, sendo potencialmente relevante para comunicação aos públicos consumidores como elementos de diferenciação.

Processos de valorização das matérias primas naturais típicas da região amazônica devem ser pensadas em consonância com os modos de vida de comunidades tradicionais que historicamente manejam e garantem a sustentabilidade desses recursos. A atividade projetual aqui apresentada se configura como um caminho para esse uso, que busca valorizar as diferentes dimensões da sociobiodivesidade no desenvolvimento de produtos locais a partir da Amazônia. Por fim, espera-se que após a atividade de co-design, seja possível desenvolver outras etapas posteriores ao lançamento da linha de mobiliário resultado deste projeto. O desenvolvimento de uma cadeia de valor, de modo a validar esta iniciativa, como produtora de outros artefatos enquanto atividade economicamente viável a esta comunidade, abrindo caminho para uma visão mais ampla das possibilidades do uso do jupatí, das técnicas artesanais locais e sua dimensão comercial. Estas atividades que se complementam visam, em conjunto, assegurar o diferencial e o alto valor agregado que estas peças poderão ter para o mercado consumidor.

\section{AGRADECIMENTOS}

À Fundação Cultural do Estado do Pará, através do Edital Prêmio Experimentação, Pesquisa e Difusão Artística 2016, ao qual este projeto foi contemplado. O certame integra o Programa Seiva de Incentivo à Arte e Cultura da Instituição.

À comunidade de artesãos, Cristo Rei pelas trocas e aprendizados sobre o modo de vida ribeirinho e marajoara.

Ao Design em rede, coletivo de designers que buscam a partir de uma relação de alteridade, desenvolver, potencializar e valorizar saberes-fazeres locais constituídos por agentes sociais em seus modos de vida. No desenvolvimento destas práticas de valorização, estão 
presentes a própria experiência individual dos participantes do coletivo no mercado do design e na atuação em territórios tradicionais, a pesquisa em design e a experiência acadêmica.

\section{REFERÊNCIAS}

KRUCKEN, Lia. Design e Território, Valorização de identidades e produtos locais. Studio Nobel, 2009.

JARDIM, Ninon Rose. Mulheres entre enfeites \& caminhos: cartografia de memórias em saberes e estéticas do cotidiano no Marajó das florestas (S.S. da Boa Vista - PA). 2013. 225f. Dissertação de mestrado Universidade Federal do Pará, Curso de Pós-Graduação em Artes.

JARDIM, Ninon Rose; FONSECA, Louise Alencar; FERREIRA, José Leuan Monteiro; RAMOS, Arão Neves de Oliveira; SUZUKI, Eric Satoro; "PROJETO GOTAS: uma experiência interdisciplinar em design no artesanato", p. 121-133 . In: Anais do 50 Simpósio Brasileiro de Design Sustentável [=Blucher Design Proceedings, v.2, n.5]. São Paulo: Blucher, 2016.

ISSN 2318-6968, DOI 10.5151/despro-sbds15-2st601a

MARTÍN-BARBERO, J. 2004. Introdução aventuras de um cartógrafo mestiço. In Ofício de cartógrafo: travessias latino-americanas de comunicação na cultura. São Paulo: Loyola.

BINDER, Thomas; BRANDT, Eva; EHN, Pelle; HALSE, Joachim. Democratic design experiments: between parliament and laboratory, (2015). CoDesign, 11:3-4, 152-165, DOI: 10.1080/15710882.2015.1081248 NIEMEYER, Lucy. Semiótica Aplicada ao Design. Rio de Janeiro: 2AB, 2009.

\section{AUTORES}

ORCID: https://orcid.org/0000-0002-2939-3755

NINON ROSE JARDIM, M.Sc. | ICA/UFPA | Doutoranda em Antropologia - Programa de Pós-graduação em Antropologia - UFPA | Correspondência para: Conj. Panorama XXI Q-31 C-09 - Mangueirão - CEP: 66640-245 BELÉM - PARÁ | Email: ninonjardim@gmail.com

ORCID: https://orcid.org/0000-0002-1898-1092

MANOELA MARIA COSTA DA COSTA | Marketing pela Fundação Getúlio Vargas (FGV) | Universidade do estado do Pará | Design | Belém, PARÁ (PA) - BRASIL | Correspondência para: Travessa Francisco Monteiro 621, casa 03, Belém - PA, 66070190) | Email: manoela.publicidade@gmail.com

ORCID: https://orcid.org/0000-0003-3617-0100

MARIANA FARO, M.Sc. | Universidade Federal do Pará | Programa de Pós-graduação em desenvolvimento sustentável do trópico úmido | Belém - PA | Correspondência para: Travessa Quintino Bocaiúva, 1827, casa 7. Nazaré. Belém, PA. 66035110 | Email: mxfaro@gmail.com

\section{COMO CITAR ESTE ARTIGO}

JARDIM, Ninon Rose; COSTA, Manoela Maria Costa da; FARO, Mariana. Cartografias do Design: Memória e Cotidianidade do Marajó das Florestas em Mobiliário de Jupati. MIX Sustentável, [S.I.], v. 5, n. 5, p. 53-66, dez. 2019. ISSN 24473073. Disponível em:<http://www. nexos.ufsc.br/index.php/mixsustentavel>. Acesso em: dia mês. ano. doi:https://doi.org/10.29183/2447-3073. MIX2019.v5.n5.53-66.

DATA DE ENVI0: 17/11/2019

DATA DE ACEITE: 18/11/2019 